Tada, R., Murray, R.W., Alvarez Zarikian, C.A., and the Expedition 346 Scientists

Proceedings of the Integrated Ocean Drilling Program Expedition 346

publications.iodp.org

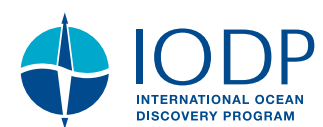

https://doi.org/10.2204/iodp.proc.346.206.2020

\section{Data report: X-ray fluorescence scanning of Site U1427, Yamato Basin, Expedition 346'}

\author{
Larry C. Peterson ${ }^{2}$ and Danielle E. Schimmenti ${ }^{2,3}$ \\ Keywords: Integrated Ocean Drilling Program, IODP, JOIDES Resolution, Expedition 346, Asian \\ Monsoon, Yamato Basin, Site U1427, XRF core scanning, sediment elemental geochemistry
}

\author{
Contents \\ 1 Abstract \\ 1 Introduction \\ 2 Methods \\ 2 Results \\ 5 Acknowledgments \\ 5 References
}

\begin{abstract}
Semiquantitative elemental results from X-ray fluorescence (XRF) scanning of sediment cores collected from Integrated Ocean Drilling Program Site U1427 in the Yamato Basin off the west coast of Japan are presented. XRF elemental data were collected every 1 $\mathrm{cm}$ from core sections located on the stratigraphically continuous Site U1427 spliced composite record over the depth interval from 13.32 to $116.71 \mathrm{~m}$ core composite depth below seafloor, Method D (CCSF-D). We report raw element intensities (counts) at subcentennial resolution for $\mathrm{Al}, \mathrm{Si}, \mathrm{K}, \mathrm{Ca}, \mathrm{Ti}, \mathrm{Fe}, \mathrm{Br}, \mathrm{Sr}$, and $\mathrm{Zr}$ and identify covariation patterns consistent with lithofacies variations that have been previously correlated with glacial-interglacial changes in sea level, sedimentation, and water-column productivity. Our high-resolution XRF scanning of Site U1427 sediments was conducted to aid in interpretation of sedimentation and facilitate more detailed paleoceanographic studies at this location.
\end{abstract}

\section{Introduction}

The major goal of Integrated Ocean Drilling Program (IODP) Expedition 346 was to collect sediment sequences to enable reconstruction of key aspects of the East Asian Monsoon and of the surface and deep circulation of the marginal sea bordered by the Eurasian continent, the Korean Peninsula, and the Japanese Islands. These objectives were met with the recovery of continuous sequences in multiple holes at a total of seven latitude- and depth-distributed sites in the marginal sea itself and at two sites in the East China Sea. We report here X-ray fluorescence (XRF) scanning results from Site U1427, the southernmost and shallowest site of the seven-site latitudinal transect (Figure F1).

The marginal sea between Japan and Korea is semienclosed and has a total area of $\sim 1 \times 10^{6} \mathrm{~km}^{2}$, a maximum depth of $3740 \mathrm{~m}$, and an average depth of $\sim 1700 \mathrm{~m}$. The sea consists of three major basins: the Japan Basin to the north, the Yamato Basin to the southeast, and the Tsushima (Ulleung) Basin to the southwest. These basins are connected with other seas through shallow, narrow straits, namely the East China Sea to the south through the Tsushima Strait $(130 \mathrm{~m}$ sill depth), the North Pacific to the east through the Tsugaru Strait (130 $\mathrm{m}$ sill depth), and the Sea of Okhotsk to the north through the Soya (55 m sill depth) and Mamiya (20 m sill depth) Straits (Tada et al., 2013). The shallow depths of these passages figure prominently in the present oceanography of the basin. At present, the Tsushima Warm Current (TWC) is the only current that flows into the marginal sea (Figure F1). Surface waters that make up the TWC form in the East China Sea by mixing of the Taiwan Warm Current, a branch of the Kuroshio Current, with Yangtze River water (Ichikawa and Beardsley, 2002).

After entering the marginal sea proper, the TWC splits into three branches. The first branch flows through the eastern channel of the Tsushima Strait (Katoh, 1993; Hase et al., 1999) and moves northeast along the Japanese coast with a relatively stable flow of 12 Sv (e.g., Isobe et al., 2002; Watanabe et al., 2007). The second branch of the TWC flows into the western side of the marginal sea through the western channel of the Tsushima Strait (Kawabe, 1982; Hase et al., 1999) and passes north along the eastern margin of the Korean Peninsula to $\sim 38^{\circ} \mathrm{N}$. The third branch of the TWC, the East Korea Warm Current, flows north along the eastern margin of the Korean Peninsula to $\sim 38^{\circ} \mathrm{N}$. Most of the surface water comprising the TWC then exits the marginal sea through the Tsugaru Strait, and the rest flows north along the western margin of Hokkaido Island and subsequently flows out through the Soya Strait into the Sea of Okhotsk.

Site U1427 is located in the Yamato Basin at $35^{\circ} 57.92 \mathrm{~N}$, $134^{\circ} 26.06^{\prime} \mathrm{E}$ and 330 meters below sea level (mbsl). The site is situated on the outer margin of the southeast-northwest-trending continental shelf $\sim 35 \mathrm{~km}$ from the northern coast of Honshu Island (Tada et al., 2015b). The location of Site U1427 was selected to obtain a high-resolution record of changes in the intensity of the influx of the first branch of the TWC, which flows along the outer margin of the continental shelf of Honshu Island (Hase et al., 1999). In addition, the proximity of the site to the southwestern portion of Hon-

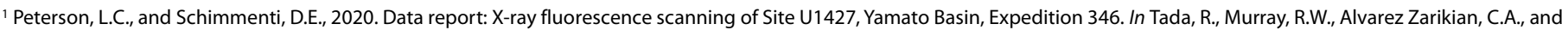
the Expedition 346 Scientists, Proceedings of the Integrated Ocean Drilling Program, 346: College Station, TX (Integrated Ocean Drilling Program). https://doi.org/10.2204/iodp.proc.346.206.2020

2 Rosenstiel School of Marine and Atmospheric Sciences, University of Miami, USA. Correspondence author: Ipeterson@rsmas.miami.edu

${ }^{3}$ Department of Geology and Geophysics, Texas A\&M University, USA.

MS 346-206: Received 16 March 2020 . Accepted 27 July 2020 . Published 3 September 2020

This work is distributed under the Creative Commons Attribution 4.0 International (CC BY 4.0) license. (c) BY
} 
Figure F1. Distribution of Expedition 346 sites in the marginal sea between Japan and Korea and the East China Sea (modified from Tada et al., 2015b). Red arrows identify the major surface current systems in the region. Site U1427 was drilled and cored in the Yamato Basin off the coast of Japan.

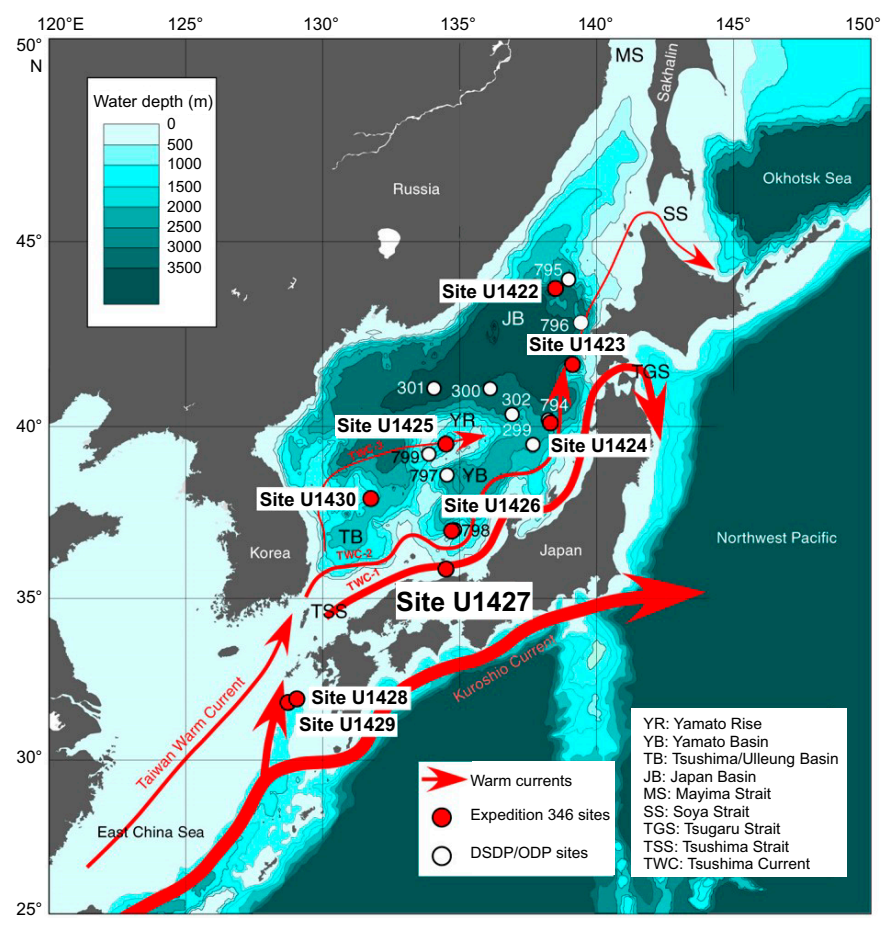

shu Island was expected to provide a rare opportunity to examine the interrelationship between terrestrial climate, oceanography, and sea level in the southern part of the marginal basin. Our XRF scanning of Site U1427 sediments was conducted to aid in interpretation of sedimentation and facilitate more detailed paleoceanographic studies at this location. In this report, raw count data for elements commonly used to identify changes in lithofacies and paleoproductivity are presented.

\section{Methods}

Since its development, the scanning XRF method has become a standard tool for analyzing the bulk chemistry of sediments (e.g., Jansen et al., 1998; Ortiz and Rack, 1999; Croudace et al., 2006; Rothwell and Croudace, 2015). Unlike traditional methods for acquiring solid-phase geochemical data that are time consuming and require physical sampling of the sediment, the nondestructive nature of XRF core scanning makes it possible to acquire high-resolution geochemical data at a rate and sampling interval that would be impractical using conventional methods. Such data can be used to augment physical property measurements collected by track systems on the R/V JOIDES Resolution to study rapid changes in sedimentation. XRF core scanning has been increasingly used in a variety of high-resolution paleoenvironmental studies (e.g., Arz et al., 1998; Peterson et al., 2000; Röhl et al., 2000; Lamy et al., 2014; Haug et al., 2001; Kuhlmann et al., 2004; Ziegler et al., 2008; Gibson and Peterson, 2014; Seki et al., 2019). These studies rely on the fact that the bulk chemistry of sediments reflects such factors as the composition and source of both the biogenic and nonbiogenic components, as well as depositional conditions, such as the redox environment.
Table T1. Scanning X-ray fluorescence data, Site U1427. Download table in CSV format.

Data in this report were acquired using the Avaatech XRF core scanner at the Rosenstiel School of Marine and Atmospheric Science (RSMAS), University of Miami (USA). The core scanner can measure elements ranging from $\mathrm{Al}$ to $\mathrm{U}$ in the periodic table, though in practice for marine sediments a more limited suite of elements proves useful for characterizing the lithogenic and biogenic components. All measurements from Site U1427 core sections were made on paleomagnetic U-channels sampled at the IODP Kochi Core Center (Japan) where the Expedition 346 cores are archived. XRF elemental data were collected every $1 \mathrm{~cm}$ from core sections included in the stratigraphically continuous Site U1427 spliced composite record with elemental data reported on the core composite depth below seafloor, Method D (CCSF-D), scale in meters (Tada et al., 2015a). We use here the updated CCSF-D depth scale of Irino et al. (2018) based on postexpedition revisions to the splice (version CCSFD_Patched_rev20170310; available as a supplementary table in Irino et al., 2018). Elemental data in this report span the spliced interval from 13.32 to 116.71 m CCSF-D. U-channels from the uppermost $13.32 \mathrm{~m}$ CCSF-D were collected for paleomagnetic investigation but were subsequently unavailable for XRF measurement. A gap in data from 71.32 to 73.20 m CCSF-D resulted from the Irino et al. (2018) revisions to the original composite splice, which occurred after U-channels had already been sampled and shipped to Miami for measurement. The total length of the recovered sediment sequence at Site U1427 was $542.6 \mathrm{~m}$, so the data presented here span roughly the upper $20 \%$ of the complete section.

Prior to scanning, each U-channel was warmed to room temperature, scraped with a glass slide to clean the exposed sediment surface, and covered with a $4 \mu \mathrm{m}$ thick Ultralene plastic film to prevent sediment contamination of the measuring prism. U-channels were warmed up prior to being covered with the film to prevent condensation build-up beneath the plastic film, which can affect Xray attenuation for the lightest elements (Tjallingii et al., 2007).

Scans were completed for each U-channel at $10 \mathrm{kV}$ and $30 \mathrm{kV}$. The $10 \mathrm{kV}$ scan used a tube current of $1 \mathrm{~mA}$, no filter, and a detection time of $10 \mathrm{~s}$ live time. Data presented here from the $10 \mathrm{kV}$ run include $\mathrm{Al}, \mathrm{Si}, \mathrm{K}, \mathrm{Ca}, \mathrm{Ti}$, and $\mathrm{Fe}$. For the $30 \mathrm{kV}$ scan, a tube current of $1 \mathrm{~mA}$, a detection time of $20 \mathrm{~s}$, and a Pd thick filter were used. Element data reported here from the $30 \mathrm{kV}$ scan include $\mathrm{Br}$, Sr, and $\mathrm{Zr}$. For all measurements, the sample irradiation area was $5 \mathrm{~mm}$ in the downcore direction and $12 \mathrm{~mm}$ in the cross-core direction. The Avaatech XRF scanner at RSMAS uses an X-ray tube with a rhodium anode to generate the incident $\mathrm{X}$-rays that illuminate the sample. More than 9900 discrete sample depths were measured, and all XRF data are presented in XRF in Table $\mathrm{T} 1$ as raw element intensities (counts).

\section{Results}

The scanning XRF data in this report provide a high-resolution record of the geochemistry of the sediments analyzed at Site U1427. Based on estimated sedimentation rates of $20-40 \mathrm{~cm} / \mathrm{ky}$ for the interval analyzed (Gallagher et al., 2018), the $1 \mathrm{~cm}$ measurement interval yields a temporal spacing of $25-50$ y between data points. Figures F2 and F3 show the downhole distributions of selected elements typically associated with lithogenic and biogenic sources, respectively. Al, $\mathrm{Si}, \mathrm{K}, \mathrm{Fe}, \mathrm{Ti}$, and to a lesser extent $\mathrm{Zr}$ (Figure F2) show positive covariance with each other, a relationship illustrated for 
Figure F2. Raw XRF scanner counts for lithogenic elements Al, Si, K, Fe, Ti, and Zr plotted on the revised Site U1427 spliced composite depth of scale of Irino et al. (2018). Horizontal dashed lines indicate stratigraphic position and ages of widely distributed tephra layers ASO-4, Ata-Th, and ASO-1.

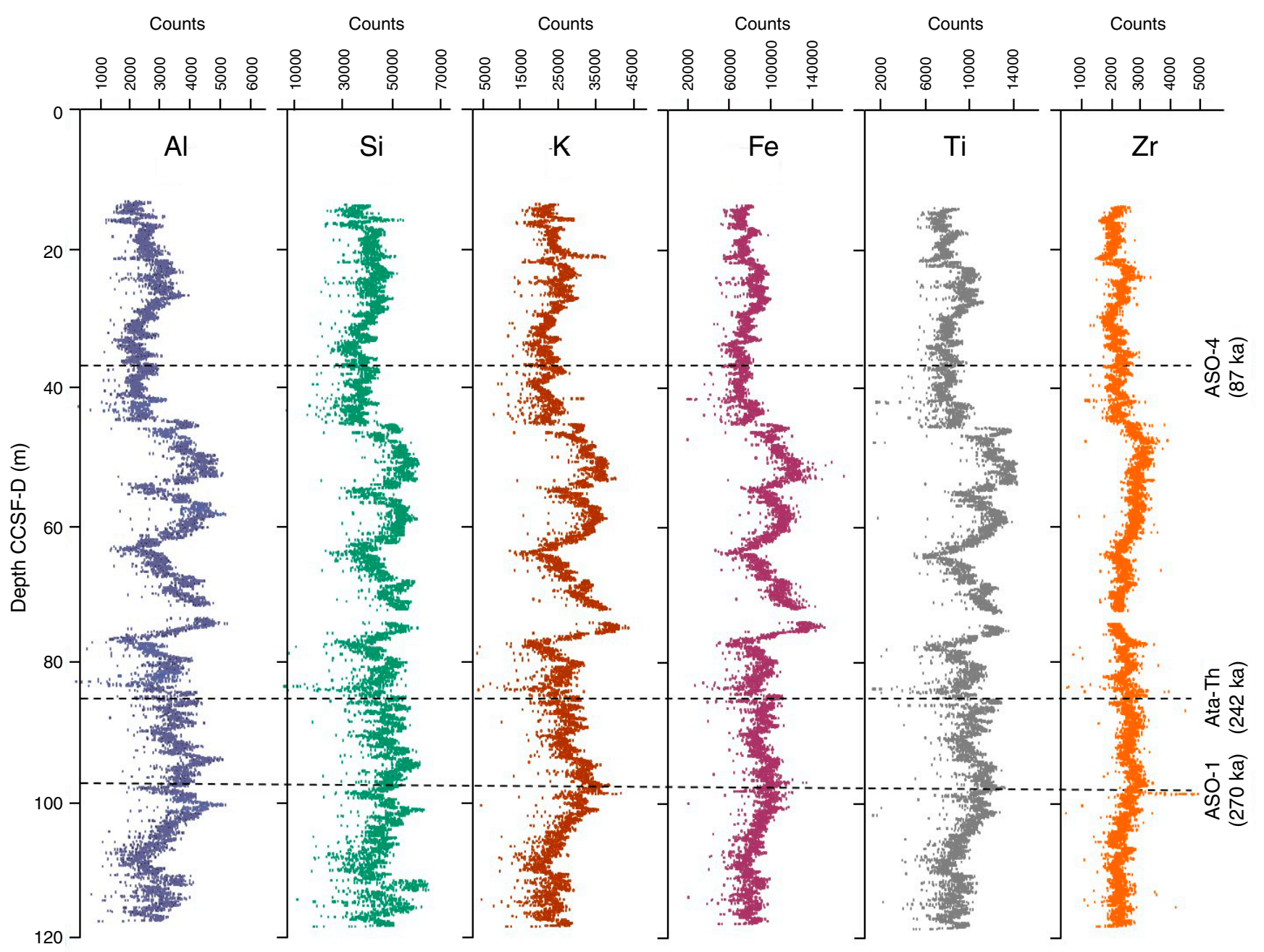

several of the element pairs ( $\mathrm{Si}$ vs. $\mathrm{Al} ; \mathrm{K}$ vs. $\mathrm{Al} ; \mathrm{Fe}$ vs. $\mathrm{Al}$ ) by the crossplots shown in Figure F4. The similar nature of downhole patterns of these elements is consistent with an interpretation that they reflect a common terrigenous origin. In contrast, $\mathrm{Ca}, \mathrm{Sr}$, and $\mathrm{Br}$ show a pattern (Figure F3) that is largely inverse and dominantly reflects the biogenic components in the sequence. $\mathrm{Ca}$ and $\mathrm{Sr}$ are closely correlated $\left(R^{2}=0.88\right)$ and expected to record the relative abundance of calcareous materials, whereas $\mathrm{Br}$ in marine sediments can be used as a proxy for the total organic carbon (TOC) content (Ziegler et al., 2008; Seki et al., 2019).

Centimeter-thick tephra layers occur frequently throughout the sequence. Three well-known tephra layers in the interval analyzed were identified by Sagawa et al. (2018), who established a tephrostratigraphy for Site U1427 and other Expedition 346 sites. These layers consist of coignimbrite ash associated with large-scale pyroclastic flow eruptions on Kyushu Island and are well dated. Though none have a distinctive elemental signature in the major elements reported here, the tephra layers could each be visually identified in the U-channel samples, and their stratigraphic position is indicated in Figures F2 and F3. The ASO-4 tephra has been dated to $87 \mathrm{ka}$ (Aoki, 2008) and is found at $37.54 \mathrm{~m} \mathrm{CCSF-D.} \mathrm{It} \mathrm{can} \mathrm{be} \mathrm{used} \mathrm{to}$ identify the approximate level of Marine Isotope Stage (MIS) 5b. Sagawa et al. (2018) adopted ages of 242 and 270 ka for the Ata-Th and ASO-1 tephra layers visible at 84.67 and $97.70 \mathrm{~m}$ CCSF-D, respectively, which bracket and help identify the interval corresponding to glacial MIS 8.

The crossplot of $\mathrm{Al}$ and $\mathrm{Ca}$ in Figure F4 shows a weak negative correlation $\left(R^{2}=0.24\right)$. The contrasting behavior of the lithogenic elements in Figure F2 and the biogenic elements of Figure F3 is consistent with shipboard sediment logs (Tada et al., 2015b) that describe the recovered sequence at Site U1427 as largely composed of silt-sized material with variable mixtures of calcareous and clayey components. Raw XRF data in counts suffer from the "closed sum" problem inherent in percentage data, so some anticorrelation between lithogenic and biogenic elements in a two-component system is not unexpected. Weltje and Tjallingii (2008) previously showed that log ratios of element intensities provide the most interpretable signals of relative changes in chemical composition. The relative proportions of the calcareous and clayey sediment end-members are thus better captured by the log ratio of calcium to titanium counts, $\ln (\mathrm{Ca} / \mathrm{Ti})$, shown in Figure F3. 
Figure F3. Raw XRF scanner counts for biogenic elements $\mathrm{Ca}$, Sr, and Br plotted on the revised Site U1427 spliced composite depth scale of Irino et al. (2018). $\ln (\mathrm{Ca} / \mathrm{Ti})$ captures the relative variability of biogenic and detrital sources at this site. Horizontal dashed lines indicate stratigraphic position and ages of widely distributed tephra layers ASO-4, Ata-Th, and ASO-1.

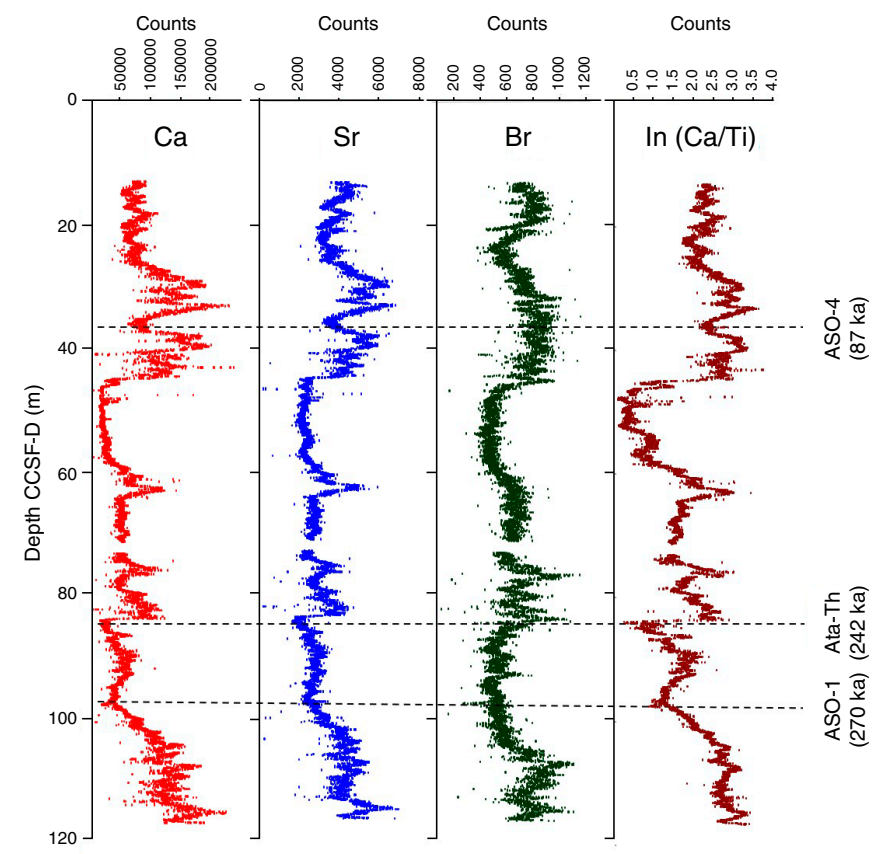

Gallagher et al. (2018) described in detail the stratigraphy and paleoceanography of Site U1427. Their results show that deposition of calcareous silts dominated during interglacial highstands of sea level, reflected here by high $\ln (\mathrm{Ca} / \mathrm{Ti})$ values, whereas more clay rich silts prevailed during the lowstands associated with glacial maxima (low $\ln [\mathrm{Ca} / \mathrm{Ti}]$ values). Gallagher et al. (2018) interpreted the increase of more clayey facies during lowstands to reflect a closer proximity to the shelf edge and to local fluvial sources of siliciclastic materials. In addition to increased dilution by clastics during lowstands, a decrease in the calcareous components may also record decreased productivity. To the extent that $\mathrm{Br}$ serves as a proxy for TOC content, the covariance of $\mathrm{Br}$ with $\ln (\mathrm{Ca} / \mathrm{Ti}$ ) (Figure $\mathrm{F} 3$ ) supports the argument that productivity changes played some role in producing the sedimentary signal.

Oba et al. (1991) proposed that isolation of the marginal sea between Japan and Korea during glacial lowstands of sea level led to extended periods of deepwater oxygen depletion that resulted in deposition of the thick, laminated, dark-colored sediments episodically found throughout the deep basin (e.g., Irino et al., 2018). This would have resulted from the restricted circulation and development of a low-salinity surface layer that stratified the upper water column and reduced deepwater ventilation (Oba et al., 1991; Tada, 1994; Tada et al., 1999). As the shallowest and most rapidly accumulating site drilled during Expedition 346, the sediments at Site U1427 were expected to provide a sensitive record of sea level impacts on sedimentation and upper water column processes in response to millennial- to orbitalscale climate variations. Elemental data presented here will hopefully augment future studies of this important sedimentary sequence.

Figure F4. Crossplots of selected elements typically associated with detrital and biogenic inputs to marine sediments: Si vs. Al, K vs. Al, Fe vs. Al, Ca vs. Al, Sr vs. Ca, and Br vs. Ca, Site U1427.
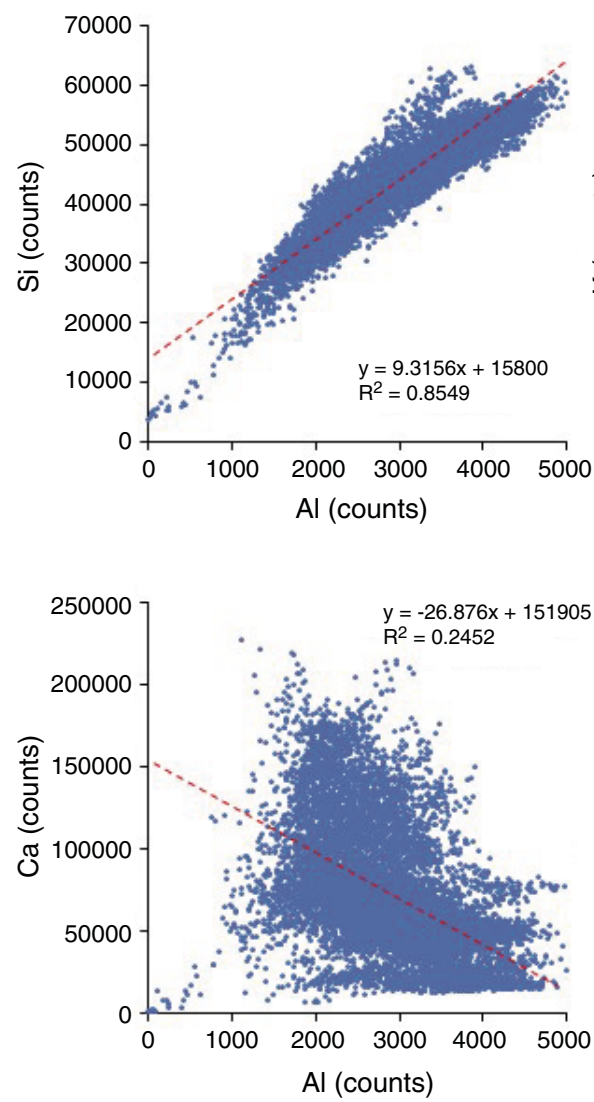
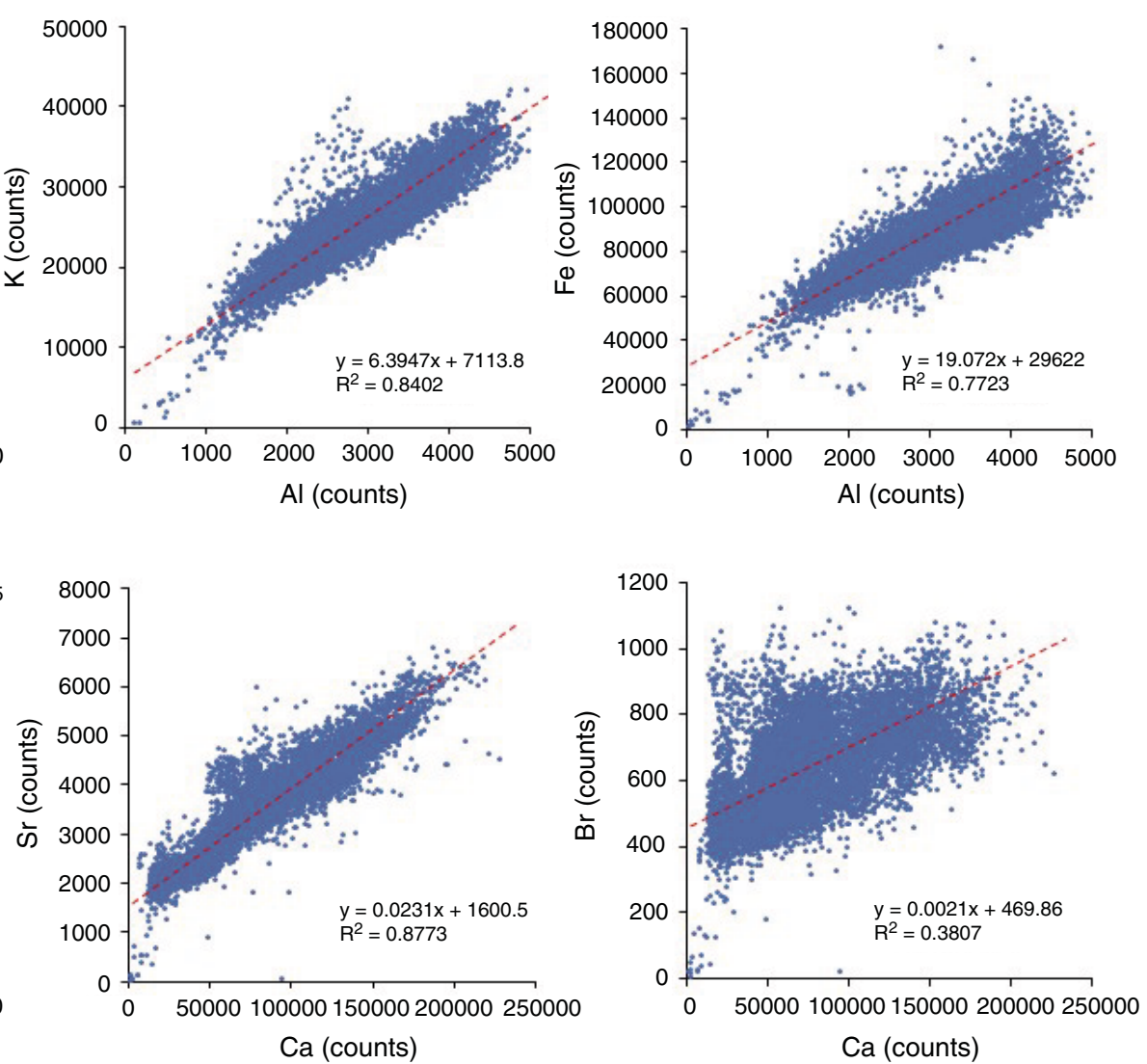


\section{Acknowledgments}

We thank Integrated Ocean Drilling Program (IODP) Expedition 346 party members, IODP, and the IODP Kochi Core Repository (Japan) for providing samples and data for this report and for all the effort expended to properly collect and archive the Site U1427 sediment cores. Funding for this research was provided by a Consortium for Ocean Leadership U.S. Science Support Program Post-Expedition Award to L.C. Peterson. We thank Denise Kulhanek for her thoughtful review and helpful suggestions.

\section{References}

Aoki, K., 2008. Revised age and distribution of ca. 87 ka Aso-4 tephra based on new evidence from the northwest Pacific Ocean. Quaternary International, 178(1):100-118. https://doi.org/10.1016/j.quaint.2007.02.005

Arz, H.W., Pätzold, J., and Wefer, G., 1998. Correlated millennial-scale changes in surface hydrography and terrigenous sediment yield inferred from last-glacial marine deposits off northeastern Brazil. Quaternary Research, 50(2):157-166. https://doi.org/10.1006/qres.1998.1992

Croudace, I.W., Rindby, A., and Rothwell, R.G., 2006. ITRAX: description and evaluation of a new multi-function X-ray core scanner. In Rothwell, R.G. (Ed.), New Techniques in Sediment Core Analysis. Special Publication Geological Society of London, 267:51-63. https://doi.org/10.1144/GSL.SP.2006.267.01.04

Gallagher, S.J., Sagawa, T., Henderson, A., Saavedra-Pellitero, M., De Vleeschouwer, D., Black, H., and Itaki, T., 2018. East Asian monsoon history and paleoceanography of the Japan Sea over the last 460,000 years. Paleoceanography and Paleoclimatology, 33(7):683-702. https://doi.org/10.1029/2018PA003331

Gibson, K.A., and Peterson, L.C., 2014. A 0.6 million year record of millennial-scale climate variability in the tropics. Geophysical Research Letters, 41(3):969-975. https://doi.org/10.1002/2013GL058846

Hase, H., Yoon, J.-H., and Koterayama, W., 1999. The current structure of the Tsushima Warm Current along the Japan coast. Journal of Oceanography, 55(2): 217-235. https://doi.org/10.1023/A:1007894030095

Haug, G.H., Hughen, K.A., Sigman, D.M., Peterson, L.C., and Röhl, U., 2001. Southward migration of the intertropical convergence zone through the Holocene. Science, 293(5533):1304-1308. https://doi.org/10.1126/science.1059725

Ichikawa, H., and Beardsley, R.C., 2002. The current system in the Yellow and East China Seas. Journal of Oceanography, 58(1): 77-92. https://doi.org/10.1023/A:1015876701363

Irino, T., Tada, R., Ikehara, K., Sagawa, T., Karasuda, A., Kurokawa, S., Seki, A., and Lu, S., 2018. Construction of perfectly continuous records of physical properties for dark-light sediment sequences collected from the Japan Sea during Integrated Ocean Drilling Program Expedition 346 and their potential utilities as paleoceanographic studies. Progress in Earth and Planetary Science, 5:23. https://doi.org/10.1186/s40645-018-0176-7

Isobe, A., Ando, M., Watanabe, T., Senjyu, T., Sugihara, S., and Manda, A., 2002. Freshwater and temperature transports through the TsushimaKorea Straits. Journal of Geophysical Research: Oceans, 107(C7):3065. https://doi.org/10.1029/2000JC000702

Jansen, J.H.F., Van der Gaast, S.J., Koster, B., and Vaars, A.J., 1998. CORTEX, a shipboard XRF-scanner for element analyses in split sediment cores. Marine Geology, 151(1-4):143-153. https://doi.org/10.1016/S0025-3227(98)00074-7

Katoh, O., 1993. Detailed current structures in the eastern channel of the Tsushima Strait in summer. Journal of Oceanography, 49(1):17-30. https://doi.org/10.1007/BF02234005

Kawabe, M., 1982. Branching of the Tsushima Current in the Japan Sea, Part I. Data analysis. Journal of the Oceanographical Society of Japan, 38(2):95107. https://doi.org/10.1007/BF02110295

Kuhlmann, H., Freudenthal, T., Helmke, P., and Meggers, H., 2004. Reconstruction of paleoceanography off NW Africa during the last 40,000 years: influence of local and regional factors on sediment accumulation. Marine Geology, 207:209-234. https://doi.org/10.1016/j.margeo.2004.03.017

Lamy, F., Gersonde, R., Winckler, G., Esper, O., Jaeschke, A., Kuhn, G., Ullermann, J., Martinez-Garcia, A., Lambert, F., and Kilian, R., 2014. Increased dust deposition in the Pacific Southern Ocean during glacial periods. Science, 343(6169):403-407. https://doi.org/10.1126/science.1245424

Oba, T., Kato, M., Kitazato, H., Koizumi, I., Omura, A., Sasaki, T., and Takayama, T., 1991. Paleoenvironmental changes in the Japan Sea during the last 85,000 years. Paleoceanography and Paleoclimatology, 6(4):499518. https://doi.org/10.1029/91PA00560

Ortiz, J.D., and Rack, F.R., 1999. Non-invasive sediment monitoring methods: current and future tools for high-resolution climate studies. In Abrantes, F., and Mix, A.C. (Eds), Reconstructing Ocean History: A Window into the Future. New York (Plenum Press), 343-380.

https://doi.org/10.1007/978-1-4615-4197-4_20

Peterson, L.C., Haug, G.H., Hughen, K.A., and Röhl, U., 2000. Rapid changes in the hydrologic cycle of the tropical Atlantic during the last glacial. Science, 290(5498):1947-1951.

https://doi.org/10.1126/science.290.5498.1947

Röhl, U., Bralower, T.J., Norris, R.D., and Wefer, G., 2000. New chronology for the late Paleocene thermal maximum and its environmental implications. Geology, 28(10):927-930. https://doi.org/10.1130/0091-7613(2000)28<927:NCFTLP>2.0.CO;2

Rothwell, R.G., and Croudace, I.W., 2015. Twenty years of XRF core scanning marine sediments: what do geochemical proxies tell us? In Croudace, I.W., and Rothwaell, R.G. (Eds.), Developments in Paleoenvironmental Research (Volume 17): Micro-XRF Studies of Sediment Cores, 25-102. https://doi.org/10.1007/978-94-017-9849-5_2

Sagawa, T., Nagahashi, Y., Satoguchi, Y., Holbourn, A., Itaki, T., Gallagher, S.J., Saavedra-Pellitero, M., Ikehara, K., Irino, T., and Tada, R., 2018. Integrated tephrostratigraphy and stable isotope stratigraphy in the Japan Sea and East China Sea using IODP Sites U1426, U1427, and U1429, Expedition 346 Asian Monsoon. Progress in Earth and Planetary Science, 5:18. https://doi.org/10.1186/s40645-018-0168-7

Seki, A., Tada, R., Kurokawa, S., and Murayama, M., 2019. High-resolution Quaternary record of marine organic carbon content in the hemipelagic sediments of the Japan Sea from bromine counts measured by XRF core scanner. Progress in Earth and Planetary Science, 6:1. https://doi.org/10.1186/s40645-018-0244-z

Tada, R., 1994. Paleoceanographic evolution of the Japan Sea. Palaeogeography, Palaeoclimatology, Palaeoecology, 108(3-4):487-508. https://doi.org/10.1016/0031-0182(94)90248-8

Tada, R., Irino, T., and Koizumi, I., 1999. Land-ocean linkages over orbital and millennial timescales recorded in late Quaternary sediments of the Japan Sea. Paleoceanography and Paleoclimatology, 14(2):236-247. https://doi.org/10.1029/1998PA900016

Tada, R., Murray, R.W., and Alvarez Zarikian, C.A., 2013. Asian Monsoon: onset and evolution of millennial-scale variability of Asian Monsoon and its possible relation with Himalaya and Tibetan plateau uplift. IODP Scientific Prospectus, 346. https://doi.org/10.2204/iodp.sp.346.2013

Tada, R., Murray, R.W., Alvarez Zarikian, C.A., Anderson, W.T., Jr., Bassetti, M.-A., Brace, B.J., Clemens, S.C., da Costa Gurgel, M.H., Dickens, G.R., Dunlea, A.G., Gallagher, S.J., Giosan, L., Henderson, A.C.G., Holbourn, A.E., Ikehara, K., Irino, T., Itaki, T., Karasuda, A., Kinsley, C.W., Kubota, Y., Lee, G.S., Lee, K.E., Lofi, J., Lopes, C.I.C.D., Peterson, L.C., SaavedraPellitero, M., Sagawa, T., Singh, R.K., Sugisaki, S., Toucanne, S., Wan, S., Xuan, C., Zheng, H., and Ziegler, M., 2015a. Methods. In Tada, R., Murray, R.W., Alvarez Zarikian, C.A., and the Expedition 346 Scientists, Proceedings of the Integrated Ocean Drilling Program, 346: College Station, TX (Integrated Ocean Drilling Program). https://doi.org/10.2204/iodp.proc.346.102.2015

Tada, R., Murray, R.W., Alvarez Zarikian, C.A., Anderson, W.T., Jr., Bassetti, M.-A., Brace, B.J., Clemens, S.C., da Costa Gurgel, M.H., Dickens, G.R., Dunlea, A.G., Gallagher, S.J., Giosan, L., Henderson, A.C.G., Holbourn, A.E., Ikehara, K., Irino, T., Itaki, T., Karasuda, A., Kinsley, C.W., Kubota, Y., Lee, G.S., Lee, K.E., Lofi, J., Lopes, C.I.C.D., Peterson, L.C., SaavedraPellitero, M., Sagawa, T., Singh, R.K., Sugisaki, S., Toucanne, S., Wan, S., 
Xuan, C., Zheng, H., and Ziegler, M., 2015b. Site U1427. In Tada, R., Murray, R.W., Alvarez Zarikian, C.A., and the Expedition 346 Scientists, Proceedings of the Integrated Ocean Drilling Program, 346: College Station, TX (Integrated Ocean Drilling Program).

https://doi.org/10.2204/iodp.proc.346.108.2015

Tjallingii, R., Röhl, U., Kölling, M., and Bickert, T., 2007. Influence of the water content on X-ray fluorescence core-scanning measurements in soft marine sediments. Geochemistry, Geophyics, Geosystems, 8(2):Q02004. https://doi.org/10.1029/2006GC001393

Watanabe, S., Tada, R., Ikehara, K., Fujine, K., and Kido, Y., 2007. Sediment fabrics, oxygenation history, and circulation modes of Japan Sea during the late Quaternary. Palaeogeography, Palaeoclimatology, Palaeoecology, 247(1-2):50-64. https://doi.org/10.1016/j.palaeo.2006.11.021

Weltje, G.J., and Tjallingii, R., 2008. Calibration of XRF core scanners for quantitative geochemical logging of sediment cores: theory and application. Earth and Planetary Science Letters, 274(3-4):423-438. https://doi.org/10.1016/j.epsl.2008.07.054

Ziegler, M., Jilbert, T., de Lange, G.J., Lourens, L.J., and Reichart, G.-J., 2008. Bromine counts from XRF scanning as an estimate of the marine organic carbon content of sediment cores. Geochemistry, Geophysics, Geosystems, 9(5):Q05009. https://doi.org/10.1029/2007GC001932 